リサイクル

\title{
一高分子基礎物性研究とプラスチックリサイクル II -
}

\section{1.はじめに}

最近ゲームなどで取り上げられているため，意外と若い 人の「三國史」の登場人物に対する認知度が高い。しかし ながら，曹操の三男である曹植に関しては，あまり関心が ないのではないかと思う。彼の詳細に関しては個別に調べ て頂きたいと思うが，何故このような話を取り上げたかと 言うと，リサイクルを取り扱っているとどうしても以下に 示す彼の「七歩詩」が頭をよぎるからである.

\section{七歩詩 \\ 豆を煮て 持て 美と作し \\ 鼓を滤して 以て汁と為す \\ 其は釜の下にありて然え 豆は釜の中にありて泣く \\ 本自から根を同じくして生じたるに 相煎ること何で太ざ急なる}

大意は，同じ境遇で生を受けたのにもかかわらず，現在は 何故このように違う扱いを受けているのか，と言うもので あるが，リサイクル樹脂も，特にプレコンシューマ品を考 えるとき，ゲートをくぐった一方は製品として高品質を追 求したものとして捉えられ, 他方は物性が劣化し異物が混 入した不用品扱いを受けている状況が，上記の詩の内容を 連想させてしまうからである．まさしく金型内に入るか入 らないかで，このように対応が異なることに，昨今感情移 入が始まったため，少々やるせなさを感じている.

昨年のこのレポートでは, 結晶性高分子のリサイクル樹 脂について，その力学的物性が劣る主要な原因の一つに, 流動（せん断）誘起結晶化を考慮する必要があることを述 べた。これは従来の再生不能な化学劣化ではなく物理劣化 と言うものであり, 最適な処理法を見出せればバージン樹 脂に類似の物性值を再現できる可能性を示唆するものであ る. 図 1 は最近の我々の研究室での実験結果をまとめたも のである1)。縦軸は破断に要するエネルギー，横軸はプレ コンシューマポリプロピレンペレットをプレス成形した条 件である. 図より，プレス成形条件如何では，プレコン シューマ樹脂はバージン樹脂並みの力学特性を示すように なることが判り, 物理劣化を考虑する必要があることが示 唆される結果となっている。

高分子鎖は変形履歴によりそのコンフォメーションが大

* Yao, Shigeru

福岡大学工学部化学システム工学科

福岡市城南区七隈 8-19-1（广 814-0180）

shyao@fukuoka-u.ac.jp

2014. 3.12 受理
きく変化する．また変化するだけでなく，それがもとで全 く異なる内部構造を形成する可能性がある. 図 2 は結晶性 高分子に関して，変形履歷が与えられた場合における内部 の高分子鎖コンフォメーションの変化を模式的に表したも のである2). 図 (a) に示す初期状態において相対するラメラ 層間に橋渡しをする形でタイモレキュールが存在し，これ が伸張挙動や耐久性を保証する役割を果たしている。図 2 (b)で融解が始まると，ラメラ層が薄くなり，その結果と してタイモレキュールのラメラ層への保持力が減少すると 考えられる。この段階で急激な伸張変形が付与された場合， 図 2 (c) に示すようにタイモレキュールは一方のラメラ層 から離脱すると考えられる。この状態で泠却され結晶化が 起こると，図 $2(\mathrm{~d})$ に示すように離脱した高分子鎖は再度 ラメラ層に戻ることはなく，ダングリングチェイン化する かあるいはその場で小さな微結晶を形成すると考えられる。 この結果，ラメラ間の接合力が低下し，化学劣化していな

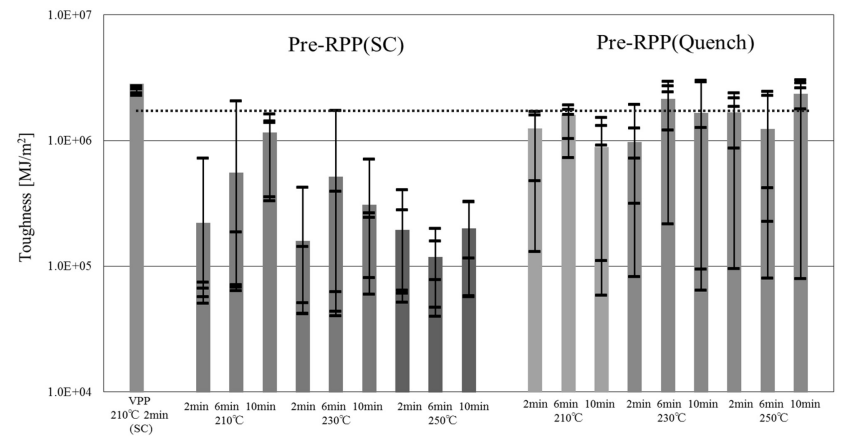

図 1 様々な熱処理, 冷却処理を施した試験片の伸張破壊 エネルギーの比較.VPPはバージンポリプロピレ ンを, Pre-RPP はプレコンシューマーポリプロピ レンを表す. $\min$ はプレス時間(分), SC は室温で の徐冷, Quench は水水での急冷を表す

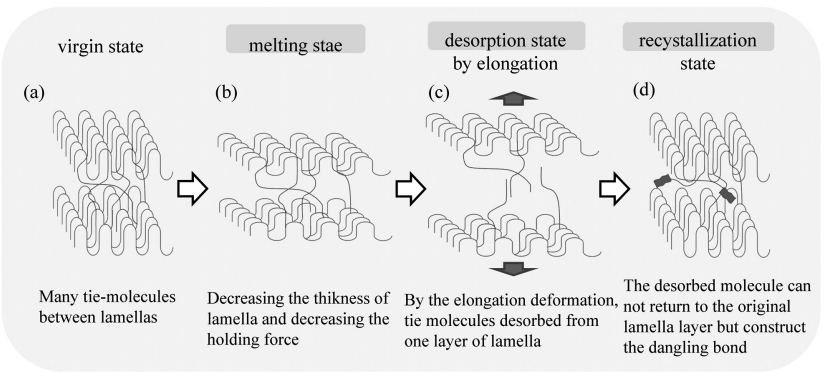

図 2 溶融伸張過程における結晶性高分子の内部構造の仮 定図 
いにも関わらず，力学特性や耐久性が低下すると考えられ る.このモデルが一般的に成立する場合，図 $2(\mathrm{~d})$ の状態 を図 2 (a)の状態に戻せば，力学特性や耐久性を改善でき ると考えられる．図1の結果は，このコンセプトに妥当性 があることを示している.

このように結晶性高分子ではラメラなどの構造体がある ために, 流動履歴の残留と言うコンセプトが成立しやすい. 一方無定形高分子はこのような構造単位が存在しないため, 流動（せん断）履歴の影響が結晶性高分子と比較してはる かに小さいと想定される. しかしながら最近の研究では,

無定形高分子も高いせん断速度領域やガラス転移温度付近 では不均質な振る舞いをすることが指摘されている．本稿 では無定形高分子について, 高いせん断速度を与えた時に 発生するシェアバンドについて触れたいと思う。またプラ スチックリサイクルの将来像に関する私見についても述べ たいと思う。

\section{2. 無定形高分子におけるシェアバンド}

通常よく絡み合いが形成されている無定形高分子あるい は溶融して無定形状態となった高分子にせん断変形を与え た場合，壁面でのスリップ現象は生じるものの，系全体は 一様な流動変形を受けると考えられている (図 $3(\mathrm{a}))$. し かしながら, 急激にせん断変形が与えられた場合, あるい は非常に高いせん断速度で変形が加えられると, そのせん 断速度に追従して流動する相と追従できずに流動する相の 複数の相に分かれる事象が発生する(図 3(b)).これがシェ アバンド現象である。溶液系のシェアバンド現象自体は, 従来ワーム状のミセルにおいて観察されてきた現象である

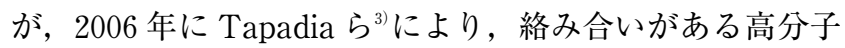
溶液においても発現することが見出された. その後多くの 研究者により，この現象が起こることが確認されてい $ろ^{4) \sim 10)}$. また最近では理論的に当該現象を取り扱う論文も 多く報告されている ${ }^{11) ~ 13)}$.

通常せん断応力はせん断速度の 1 乗に比例して増加する が，これらの論文の報告によると，シェアバンド現象が発 生すると，図 4 に示すようにせん断応力がせん断速度に依 存しなくなる, 減少する, あるいは依存性が異なるように なる ${ }^{5)}$ 。この状態で, 流動速度を測定すると, 2 層以上に 分離した流れ場を観察することが出来る.

このような現象は，管模型で考えると，図 5 に示すよう に高分子鎖が管に沿って縮む短時間領域での緩和現象より もはやい速度で高分子鎖がせん断変形を受ける硬化現象と, それによる絡み合いからの離脱として捉えることが出来そ うである ${ }^{11}$. 現象論的にこの境界領域において高分子鎖は

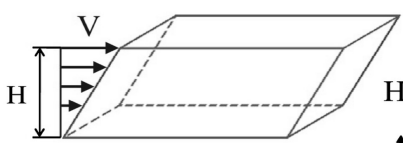

(a) homogeneous shear
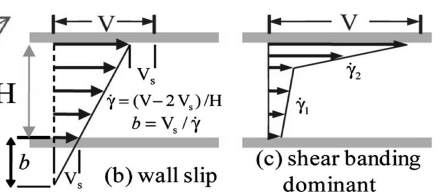

図 3 せん断変形下での高分子の流れのモデル図. (b) は 通常のせん断流動 $(\mathbf{c})$ はシェアバンドが生じた時の 流動.（c）では 2 段となっている.

Shi-Qing Wang; S. Ravindranath ; P. E. Boukany ; Macromolecules, 44, 183(2011)
完全に絡み合いから互に離脱していると考えることが出来 る.すると流動中は製品内に亀裂が走っていることになり， 不良品発生の原因ともなりそうである。従って，そうなら ないためには, 流動停止後に相互拡散により速やかに再度 均一化が起こることが必要である.

プラスチックの射出成形のプロセスを考えた時，高いせ ん断速度で金型内に充填される個所には当該現象が発生し ていると考えられる. 特に, 成形時の副生物としてリサイ クルに回されるスプールやランナーは，なるべくそのよう な副生物の発生量を抑えるために，その体積を小さくする 目的で径が細くあるいは膜厚が薄く設計されている場合が 多いため，その確率は高いと考えられる．実際にこれらの 部位でシェアバンド現象が発生しているかは, 今後の詳細 な検討を待たねばならないが，明確なシェアバンドが見ら れない場合でも，高分子鎖の状態が通常とは異なる可能性 は極めて高い.

無定形高分子では，このような流動履歴は速やかに緩和 すると考えられているが, 最近の我々の研究では異なる金 型のこれら副生物から採取した試料とバージンペレットの 成形品の引張物性は, 各々すべて異なるという結果を得て

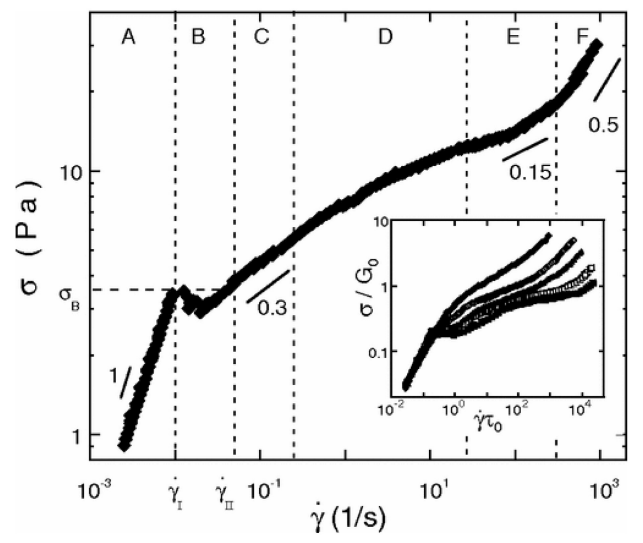

図 4 せん断速度に対するせん断応力の関係のモデル図. (A) ではせん断速度と応力の関係が比例しており, 通常の流動を表す.（B)〜 (F)はシェアバンドが生 じた時のせん断速度と応力との典型的な関係を表す. (B)では逆に減少を示している. (C)〜 (F) では依存 性が 1 よりも小さくなっている.

J. Van der Gucht, M. Lemmers, W. Knoben, N. A. M. Besseling, and M. P. Lettinga, Phys. Rev. Lett., 97, 108301 (2006)

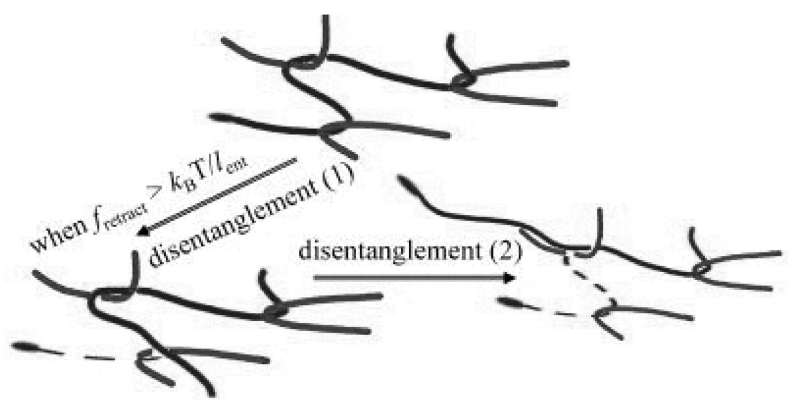

図 5 シェアバンド形成時の絡み合いの変化のスキーム図. 強いせん断変形により, 絡み合いが解消される. Shi-Qing Wang, Sham Revindranath, Yangyang Wang, and Pouyan Boukany, J. Chem. Phys., 127, $064903(2007)$ 
いる．流動変形の履歴の全ての影響を消去するためには， 最長緩和時間以上の時間が必要である可能性は, 結晶性高 分子と同様否定できない可能性も考えられる.

なお，現有の CAEでは当該現象を再現することが出来 ないようである。しかし射出成形での成形がより精密かつ 微細になり，昨今では薄膜の射出成形も行われるように なってきている. 当然金型内流動も高いせん断速度となっ ており，シェアバンドあるいはそれに至る類似な相分離が 生じる可能性も想定すべきかと思われる．成形中での当該 現象を考慮する際，もっとも大きな課題はシェアバンドが 発生する臨界せん断速度である. 現状は精度の高い実験を 行うしか求める手法はない. 但し, 比較的大きな形を取り 扱うことのできる粗視化分子動力学計算は, 高いせん断速 度での変形のシミュレーションが可能であり,この現象を 計算機上で再現できる可能性がある ${ }^{14)}$. 関係者の方の一慮 をお願いしたい。

\section{3．プラスチックリサイクルの将来像}

プラスチックのリサイクルに，サーマルリサイクル，ヶ ミカルリサイクル，マテリアルリサイクルの 3 種類がある ことはよく知られている. またこの中でもマテリアルリサ イクルがライフサイクルアセスメント的にも最も有意であ ることも, 示唆されている. 一方日本での実情は, 図 6 に 示されるように, マテリアルリサイクルの比率はここ数年 全く伸びていない ${ }^{15)}$.この原因としては, プレコンシュー マ品であっても物性が大きく劣化していること，かつこの 原因が修復不可能な化学劣化であるとされていたことを挙 げることが出来る. しかし, リサイクル樹脂の物性劣化原 因が物理劣化であり, リサイクルプロセスを最適化するこ とにより, バージン品レベルまでに再生できる可能性が示 唆されたことは, マテリアルリサイクルの推進に大きく寄 与するものと考えられる.

既にマテリアルリサイクルが進んでいる素材としては, 「紙」を上げることが出来る，紙は図 6 (a)に示すようにそ の種類により再生用途が大体決まっており，例えば新聞紙
は大半また新聞紙として利用され，雑誌はボール紙あるい は段ボールなどに再生される。 そして最終段階としてトイ レットペーパーや焼却処理に回されるスパイラルルーチン が確立している素材である ${ }^{16)}$.

現在のプラスチックリサイクルは原料ごとの分別につい ては考慮されている。しかし回収プラスチックの分子量・ 流動性あるいは結晶化度などの特性に合った再生処理のプ ロセスが未確立であるため, どのような良い素性の廃棄プ ラスチックであっても, その特性を生かした高付加価值用 途への再利用の道は閉ざされており，すべてまとめてパ レットや擬木の充填用途に利用されているのが現状である。 一方で PET ボトルのリサイクルルーチンが良好に回って いる例としてょくあげられるが，これも対象を PET ボト ルに限定しているからこそ，と考えることが出来る。つま り回収プラスチックも，その利用されていた分野あるいは 物性ごとに再利用に適した用途に適用すれば，より効果的 にリサイクルルーチンを回すことが出来ると考えられる. 紙のリサイクルルーチンがセルロースと言うある一つの種 類のプラスチックのリサイクルルーチンを表していると考 えるならば，例えば図 7 に一例を示すように，ポリエチレ ンはポリエチレンでのリサイクルルーチン, ポリスチレン はポリスチレンでのリサイクルルーチンがあるような多分 岐・多段階ルーチンを構想し, 最終的にエネルギー資源と

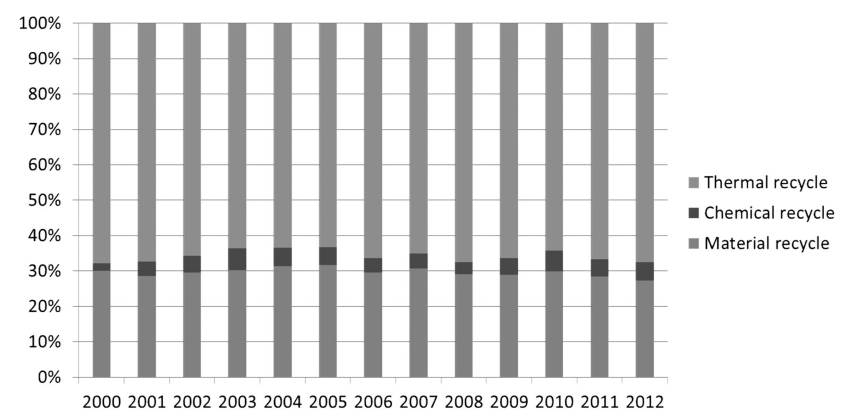

図 62000 年から 2012 年までの各種リサイクルが行われ た樹脂の割合

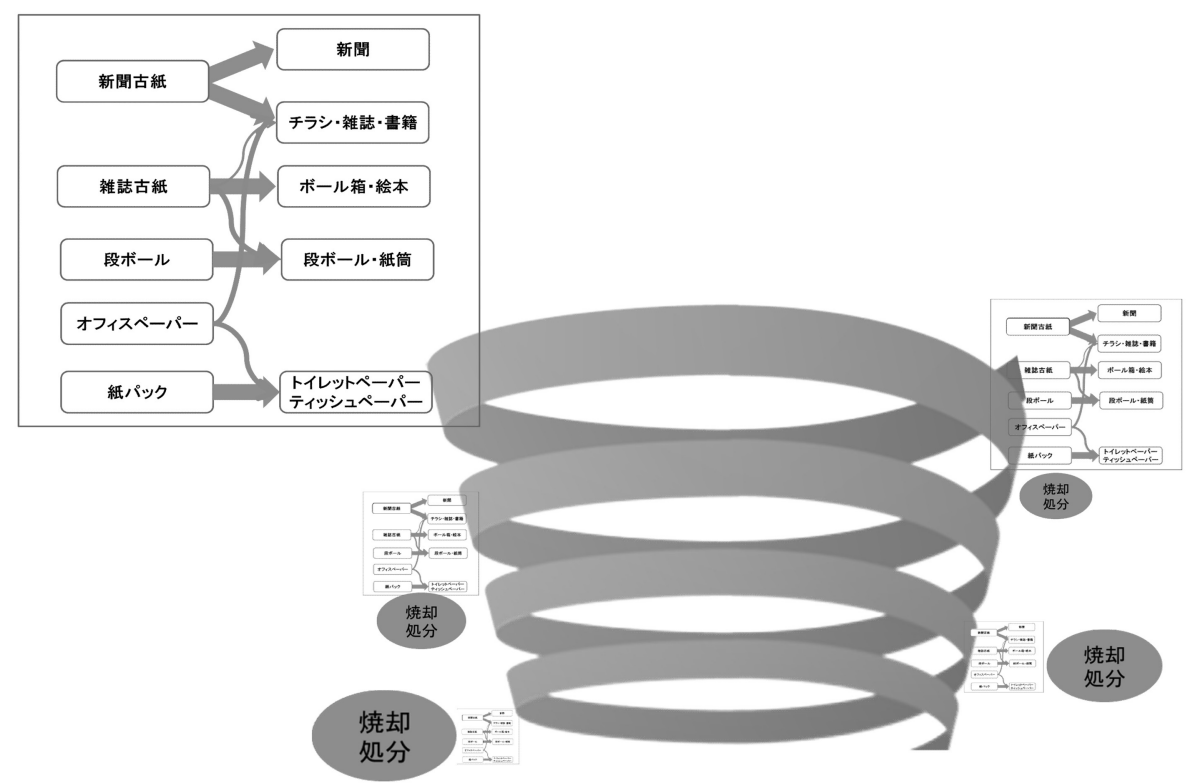

図 7 紙のリサイクルを表すスパイラル図. 徐々にリサイクルできなくなり, 焼却処分などに処せられる量が増す 


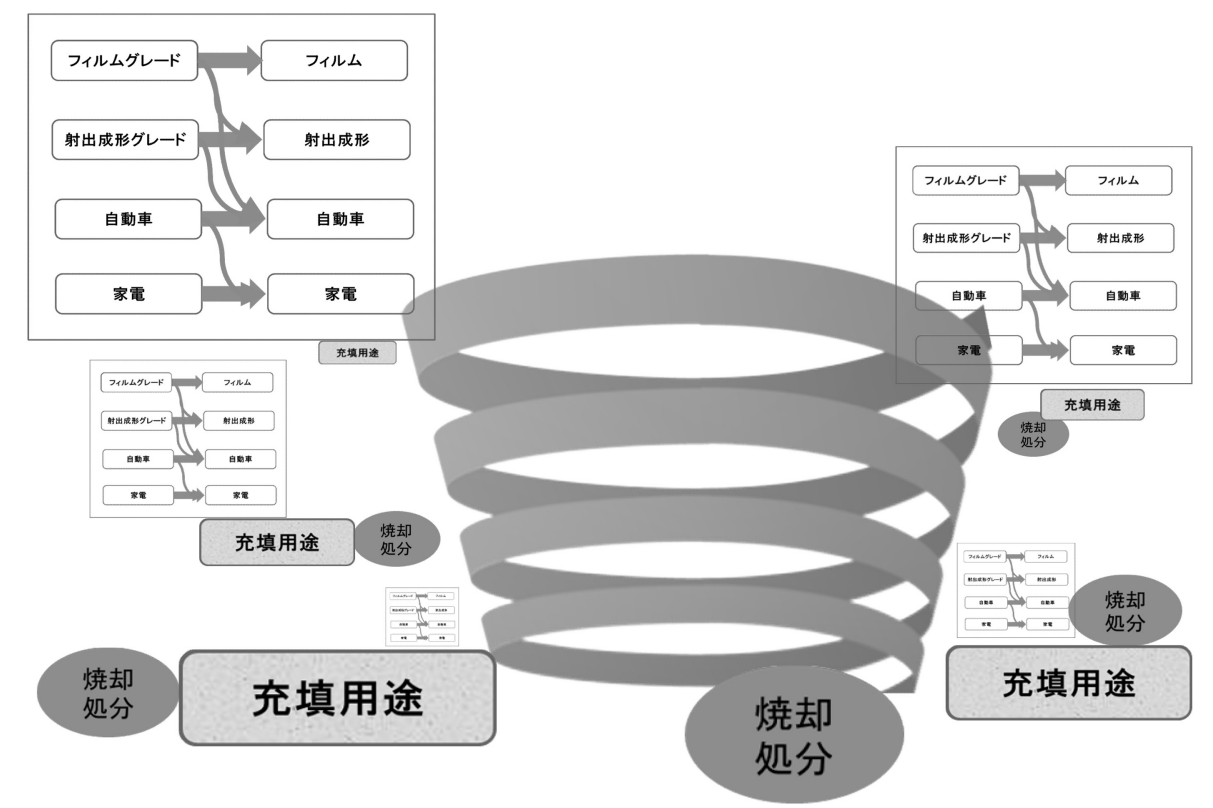

図 8 プラスチックリサイクルの将来的なモデル図. 樹脂物性に応じたリサイクルが実施され，そのルーチンからずれる 物性の樹脂が充填用途や焼却処分に回される. その量はスパイラルに従い, 初期は少なく, 徐々に増加する

して利用する流れを構築することが必要と考えられる。

\section{4. 最 後に}

リサイクルプラスチックに関しては，使い古したもので あり, 污れたものであり, 混じり物であるという意識から, それらが本来保有している物性值に関する詳細な検討がな されないままに，「処理」されてきたという側面が強い. しかし，良い特性が出せないことの原因を素材に帰着する のではなく，どのようにして良い特性を出せるかの工夫を することが技術者の本領ではないだろうか.これまで培っ てきたプラスチックに関する種々の知恵を投入し，積極的 に関わっていく時節が間近に来ていると思われる.

\section{参 考 文 献}

1 ) 冨永亜矢, 関口博史, 中野涼子, 八尾滋, 高取永一： 成形加工シンポジア ‘13，283(2013)

2 ) 冨永亜矢, 関口博史, 中野涼子, 八尾滋, 高取永一: 高分子論文集，70，712(2013)

3 ) Tapadia, P., Ravindranath, S. and Wang, S. Q. : Phys. Rev. Lett., 96, 196001 (2006)

4 ) Wang, S. Q., Ravindranath, S., Boukany, P., Olechnowicz, M., Quirk, R. R., Halasa, A. and Mays, J. : Phys. Rev. Lett. 97, 187801 (2006)

5 ) van der Gucht, J., Lemmers, M., Knoben, W., Besseking, N. A. M. and Lettinga, M. P. : Phys. Rev. Lett., 97, 108301 (2006)
6 ) Hu Y. T. : J. Rheol., 54, 1307 (2010)

7 ) Wang, S. Q., Ravindranath, S. and Boukany, P. : Macromolecules, 44, 183 (2011)

8 ) Adams, J. M., Fielding, S. M. and Olmsted, P. D. : $J$. Rheol, 55, 1007 (2011)

9 ) Cao, J. and Likhtman, E. : Phys. Rev. Lett., 108, 028302 (2012)

10) Cheng, S. and Wang, S. Q. : J. Rheology, 56, 1413 (2012)

11) Wang, S. Q, Ravindranath, S., Wang, Y, S and Boukany, P. : J. Chem. Phys., 127, 064903 (2007)

12) Fardin, M. A., Ober, T. J., Gay, C., Grégoire, G., McKinley, G. H. and Lerouge, S. : EPL, 96, 44004 (2011)

13) Cromer, M., Villet, M. C., Fredrickson, G. H. and Leal, L. G. : Physics of Fluids, 25, 051703 (2013)

14）高分子材料シミュレーションーOCTA 活用事例集 -, 公益社団法人 新化学技術推進協会/編, 化学工業日 報社， 2014 年 3 月発刊

15）「2012 年プラスチック製品の生産・廃棄・再資源化・ 処理処分の状況」から作成,一般社団法人 プラスチッ ク循環利用協会, 2013 年 12 月発行

16)「古紙の品質を守るために一異物混入の現状と対策(第 3-2 版)」から作成, 公益社団法人古紙再生促進セン ター, 2013 年 5 月 